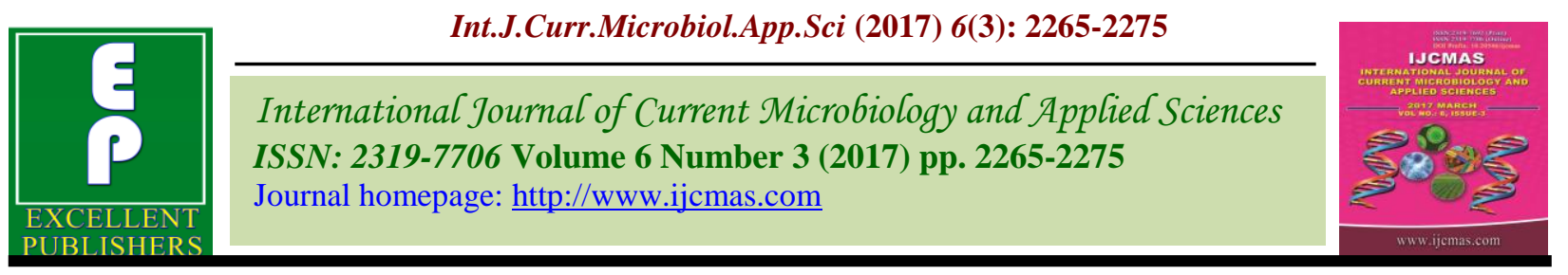

Original Research Article

http://doi.org/10.20546/ijcmas.2017.603.259

\title{
An Economic Analysis of Changes in the Per Capita Nutrient Intake and Nutritional Inadequacy in Tamil Nadu, India
}

\author{
P. Naveen Kumar*, K. Thomas Felix and D. David Rajasekar \\ Department of Agricultural Economics, Tamil Nadu Agricultural University, \\ Coimbatore-641003, India \\ *Corresponding author
}

\begin{abstract}
A B S T R A C T
Food is very essential for our existence in planet earth and food nourishes the body. Proper nutrition may mean the provision of all the essential nutrients

Keywords

Per capita nutrient intake, NSSO, RDA, Households, and Tamil Nadu.

Article Info

Accepted:

24 February 2017

Available Online:

10 March 2017 required for healthy functioning of the body through diet. The present study is undertaken to examine the changes in the per capita daily dietary nutrient intake and level of nutritional inadequacy across different socio-economic classes in Tamil Nadu over years. Secondary data was collected from NSSO household consumer expenditure survey from 61st round to 68th rounds. The study revealed that nutrient gap got widened in the case of nutrients such as carbohydrate, protein, calcium, vitamin $\mathrm{B} 1$, vitamin $\mathrm{B} 2$ vitamin $\mathrm{B} 6$ and vitamin $\mathrm{C}$ and the intake exceeded the RDA in vitamin $\mathrm{C}$ and phosphorus in both rural and urban households over years. Many efforts were made on the part of Department of Health and Family Welfare to create awareness on the importance of major and minor nutrients, minerals, vitamins and the production, popularization and distribution of the food preparations containing all these nutrients have become the need of the hour and the allocation of required resources towards the creation of awareness and supply of nutrient rich food preparation should be undertaken in all the districts of Tamil Nadu, India.
\end{abstract}

\section{Introduction}

Food is very essential for our existence in planet earth and food nourishes the body. Food may be viewed as anything eaten or drunk, which meets the needs for energy, building, regulation and protection of the body. Proper nutrition may mean the provision of all the essential nutrients required for healthy functioning of the body through diet. Shortage in these nutrients may have adverse effects on the overall functioning of the body. There are many different nutrients needed to be consumed in order to maintain healthy function of the body. These nutrients include vitamins and minerals, fats, carbohydrates, and proteins. In addition to supplying energy, the above nutrients also have other specific functions to be performed with in human body. The deficiency and the improper access of these nutrients may cause an organ or the whole system to fail. For instance, potassium deficiency may cause muscle cramps and calcium deficiency cause heart and bone diseases. Thus balanced nutrition along with 
the regular physical exercise is inevitable for leading a healthy life. Over the years, due to expanding urbanization and sedentary lifestyle, there has been an increase in diet of fat and sugars and a reduction in intake of carbohydrate, dietary fibres and essential micro nutrients (Popkin, 2009). Similarly, Deaton et al., (2009) has indicated a sustained decline in the percapita consumption of energy, protein and other nutrients but it was not applicable to fat consumption which has increased steadily during this period. These changes in the food consumption pattern in India are due to the demographic and socioeconomic changes, which include a rise in income, changes in relative prices of commodities, dietary changes, emerging middle income class, increasing numbers of working women, changes in lifestyles, fast urbanization, improvements in transportation and storage facilities, rise of supermarkets and rising importance of single person households. It is estimated that the Tamil Nadu may require total food grain production of 12.32 million tons in the year 2020 to meet the consumption demand alone without considering the industrial demand, While the production realized currently during 2010-11 was only about 7.59 million tones, leaving a large demand and supply gap of 4.76 million tones (Twelfth Five Year Plan, Tamil Nadu, 2017). The present study is undertaken to examine the changes in the per capita daily dietary nutrient intake and level of nutritional inadequacy across different socio-economic classes in Tamil Nadu over years.

\section{Materials and Methods}

The data collected by the National Sample Survey Organisaton (NSSO) for the 61st round (2004-05) and 68th round (2011-2012) have been used for estimating the nutrient intake of different nutrients across different households of Tamil Nadu. For analysis the quantities of nutrient and calorie intake by the household was calculated by multiplying the total consumption of a particular pulse commodity with conversion factors given by Gopalan et al., (1996). This procedure has been used by NSSO in arriving at the calories consumed.

In the present study used state-wise poverty line to classify the entire sample size as low, middle and high income classes. For this, poverty estimates, released by the Planning Commission, Government of India for 200405 and 2011-12 were used for each individual state. Accordingly, the 'low income' class comprised households who have income level below the poverty line (BPL), between BPL and up to 150 per cent of BPL was grouped as 'middle income' and households having per capita income above 150 per cent of BPL were categorized as 'high income' group. In this paper, percentage and average analyses were used to analyze per day per capita intake of different types of nutrients among different households across income groups to delineate the changes in the food consumption pattern and nutritional adequacy in Tamil Nadu.

\section{Results and Discussion}

Average per day per capita intake of different types of nutrients among low income households in rural regions of Tamil Nadu is presented in table 1 and depicted as figure 1. From table 1, it could be observed that average intake of all the nutrients were decreased, except crude fibre, iron and vitamins A, B12 and C between 2004-05 and 2011-12. The maximum decrease in the nutrients was observed in the case of energy and phosphorus. The comparative analysis on the nutritional gap with respect to Recommended Daily Dietary Allowances (RDA) between 2004-05 and 2011-12 indicated that the degree of existing gap in 2004-05 got widened in the case of nutrients such as protein, carbohydrates, calcium, 
vitamin B1, B2 and B6. In the case of phosphorus and Vitamin $\mathrm{C}$, the intake was found to be more than RDA in 2004-05 while the intake decreased in the case of phosphorus and increased in the case of Vitamin $\mathrm{C}$ in 2011-12.

Average per day per capita intake of different types of nutrients among middle income households in rural regions of Tamil Nadu is presented in table 2 and depicted as figure 2 . From table 2, it could be observed that average intake of all the nutrients were decreased, except crude fibre, iron and vitamins B12 and C between 2004-05 and
2011-12. The maximum decrease in the nutrients was observed in the case of energy and calcium. The comparative analysis on the nutritional gap with respect to Recommended Daily Dietary Allowances (RDA) between 2004-05 and 2011-12 indicated that the degree of existing gap in 2004-05 got widened in the case of nutrients such as energy, Vitamin A and B2. In the case of phosphorus and calcium, the intake was found to be more than RDA in 2004-05 while the intake decreased in the case of phosphorus and increased in the case of Vitamin $\mathrm{C}$ in 2011-12.

Table.1 Average intake of different nutrients among low income rural households in Tamil Nadu

\begin{tabular}{|c|c|c|c|c|c|c|}
\hline \multirow[b]{2}{*}{ Foods/Nutrients } & 2004-05 & 2011-12 & \multirow{2}{*}{$\begin{array}{c}\text { Change } \\
\text { between } \\
\text { periods }\end{array}$} & \multirow{2}{*}{$\begin{array}{c}\text { Standard } \\
\text { per day } \\
\text { requirement* }\end{array}$} & \multirow{2}{*}{$\begin{array}{c}\text { Nutrient } \\
\text { gap } \\
2004-05\end{array}$} & \multirow{2}{*}{$\begin{array}{c}\text { Nutrient } \\
\text { gap } \\
\text { 2011-12 }\end{array}$} \\
\hline & Mean & Mean & & & & \\
\hline Protein $(\mathrm{g})$ & 45.96 & 41.95 & -4.01 & 60 & -14.04 & -18.05 \\
\hline Fat $(\mathrm{g})$ & 36.56 & 19.95 & -16.61 & 30 & 6.56 & -10.05 \\
\hline Crude fibre $(\mathrm{g})$ & 5.99 & 6.47 & 0.48 & 40 & -34.01 & -33.53 \\
\hline Carbohydrates (g) & 328.58 & 301.92 & -26.66 & 375 & -46.42 & -73.08 \\
\hline Energy K.cal. & 1833.20 & 1558.90 & -274.3 & 2730 & -896.8 & -1171.1 \\
\hline Calcium (mg) & 433.07 & 335.69 & -97.38 & 600 & -166.93 & -264.31 \\
\hline Phosphorus (mg) & 1077.86 & 970.60 & -107.26 & 600 & 477.86 & 370.60 \\
\hline Iron (mg) & 16.62 & 17.42 & 0.8 & 17.00 & -0.38 & 0.42 \\
\hline $\begin{array}{c}\text { Vitamin A } \\
\text { carotene }(\mu \mathrm{g})\end{array}$ & 1181.65 & 1298.99 & 117.34 & 4800 & -3618.35 & -3501.01 \\
\hline $\begin{array}{c}\text { Vitamin B1 } \\
\text { thiamine (mg) }\end{array}$ & 1.39 & 1.29 & -0.1 & 1.40 & -0.01 & -0.11 \\
\hline $\begin{array}{c}\text { Vitamin B2 } \\
\text { riboflavin }(\mathrm{mg})\end{array}$ & 0.73 & 0.60 & -0.13 & 1.60 & -0.87 & -1 \\
\hline $\begin{array}{l}\text { Vitamin B6 niacin } \\
(\mathrm{mg})\end{array}$ & 16.60 & 15.83 & -0.77 & 18.00 & -1.4 & -2.17 \\
\hline $\begin{array}{l}\text { Vitamin B12 folic } \\
\text { acid (mg) }\end{array}$ & 127.75 & 133.67 & 5.92 & 200 & -72.25 & -66.33 \\
\hline Vitamin C (mg) & 73.26 & 93.24 & 19.98 & 40 & 33.26 & 53.24 \\
\hline
\end{tabular}

* Standard revised daily dietary allowances for moderate work category

Source: Revised Recommended Dietary Allowances for Indians - 2010, (Moderate category) National Institute of Nutrition (ICMR), Hyderabad 
Table.2 Average intake of different nutrients among middle income rural households in Tamil Nadu

\begin{tabular}{|c|c|c|c|c|c|c|}
\hline \multirow{2}{*}{ Nutrients } & 2004-05 & 2011-12 & \multirow{2}{*}{$\begin{array}{c}\text { Change } \\
\text { between } \\
\text { periods }\end{array}$} & \multirow{2}{*}{$\begin{array}{c}\text { Standard } \\
\text { per day } \\
\text { requirement* }\end{array}$} & \multirow{2}{*}{$\begin{array}{c}\text { Nutrient } \\
\text { gap } \\
\text { 2004-05 }\end{array}$} & \multirow{2}{*}{$\begin{array}{c}\text { Nutrient } \\
\text { gap } \\
\text { 2011-12 }\end{array}$} \\
\hline & Mean & Mean & & & & \\
\hline Protein $(\mathrm{g})$ & 64.63 & 53.53 & -11.1 & 60 & 4.63 & -6.47 \\
\hline Fat $(\mathrm{g})$ & 83.98 & 33.43 & -50.55 & 30 & 53.98 & 3.43 \\
\hline Crude fibre $(\mathrm{g})$ & 7.65 & 8.76 & 1.11 & 40 & -32.35 & -31.24 \\
\hline Carbohydrates (g) & 399.48 & 333.22 & -66.26 & 375 & 24.48 & -41.78 \\
\hline Energy K.cal. & 2625.04 & 1853.62 & -771.42 & 2730 & -104.96 & -876.38 \\
\hline Calcium (mg) & 781.06 & 458.25 & -322.81 & 600 & 181.06 & -141.75 \\
\hline Phosphorus (mg) & 1503.41 & 1188.88 & -314.53 & 600 & 903.41 & 588.88 \\
\hline Iron $(\mathrm{mg})$ & 20.99 & 22.26 & 1.27 & 17.00 & 3.99 & 5.26 \\
\hline Vitamin A carotene $(\mu \mathrm{g})$ & 1938.70 & 1822.72 & -115.98 & 4800 & -2861.3 & -2977.28 \\
\hline Vitamin B1 thiamine (mg) & 1.78 & 1.54 & -0.24 & 1.40 & 0.38 & 0.14 \\
\hline Vitamin B2 riboflavin (mg) & 1.22 & 0.81 & -0.41 & 1.60 & -0.38 & -0.79 \\
\hline Vitamin B6 niacin (mg) & 20.25 & 17.64 & -2.61 & 18.00 & 2.25 & -0.36 \\
\hline Vitamin B12 folic acid (mg) & 169.77 & 172.76 & 2.99 & 200 & -30.23 & -27.24 \\
\hline Vitamin C (mg) & 103.43 & 126.58 & 23.15 & 40 & 63.43 & 86.58 \\
\hline
\end{tabular}

Table.3 Average intake of different nutrients among high income rural households in Tamil Nadu

\begin{tabular}{|c|c|c|c|c|c|c|}
\hline \multirow[b]{2}{*}{ Nutrients } & 2004-05 & 2011-12 & \multirow{2}{*}{$\begin{array}{l}\text { Change } \\
\text { between } \\
\text { periods }\end{array}$} & \multirow{2}{*}{$\begin{array}{c}\text { Standard } \\
\text { per day } \\
\text { requirement* }\end{array}$} & \multirow{2}{*}{$\begin{array}{l}\text { Nutrient } \\
\text { gap } \\
2004-05\end{array}$} & \multirow{2}{*}{$\begin{array}{c}\text { Nutrient } \\
\text { gap } \\
\text { 2011-12 }\end{array}$} \\
\hline & Mean & Mean & & & & \\
\hline Protein $(\mathrm{g})$ & 90.17 & 69.82 & -20.35 & 60 & 30.17 & 9.82 \\
\hline Fat $(\mathrm{g})$ & 159.24 & 50.59 & -108.65 & 30 & 129.24 & 20.59 \\
\hline Crude fibre $(\mathrm{g})$ & 10.10 & 11.84 & 1.74 & 40 & -29.9 & -28.16 \\
\hline Carbohydrates (g) & 444.45 & 364.18 & -80.27 & 375 & 69.45 & -10.82 \\
\hline Energy K.cal. & 3595.13 & 2200.24 & -1394.89 & 2730 & 865.13 & -529.76 \\
\hline Calcium (mg) & 1329.01 & 620.44 & -708.57 & 600 & 729.01 & 20.44 \\
\hline Phosphorus (mg) & 2054.65 & 1463.52 & -591.13 & 600 & 1454.65 & 863.52 \\
\hline Iron $(\mathrm{mg})$ & 26.66 & 28.37 & 1.71 & 17.00 & 9.66 & 11.37 \\
\hline Vitamin A carotene $(\mu \mathrm{g})$ & 3161.60 & 2610.28 & -551.32 & 4800 & -1638.4 & -2189.72 \\
\hline Vitamin B1 thiamine (mg) & 2.19 & 1.83 & -0.36 & 1.40 & 0.79 & 0.43 \\
\hline Vitamin B2 riboflavin (mg) & 1.97 & 1.10 & -0.87 & 1.60 & 0.37 & -0.5 \\
\hline Vitamin B6 niacin (mg) & 22.74 & 19.67 & -3.07 & 18.00 & 4.74 & 1.67 \\
\hline $\begin{array}{l}\text { Vitamin B12 folic acid } \\
\text { (mg) }\end{array}$ & 226.83 & 225.72 & -1.11 & 200 & 26.83 & 25.72 \\
\hline Vitamin C (mg) & 154.30 & 181.12 & 26.82 & 40 & 114.3 & 141.12 \\
\hline
\end{tabular}


Table.4 Average intake of different nutrients among low income urban households in Tamil Nadu

\begin{tabular}{|c|c|c|c|c|c|c|}
\hline \multirow[b]{2}{*}{ Nutrients } & 2004-05 & 2011-12 & \multirow{2}{*}{$\begin{array}{c}\text { Change } \\
\text { between } \\
\text { periods }\end{array}$} & \multirow{2}{*}{$\begin{array}{c}\text { Standard } \\
\text { per day } \\
\text { requirement* }\end{array}$} & \multirow{2}{*}{$\begin{array}{l}\text { Nutrient } \\
\text { gap } \\
2004-05\end{array}$} & \multirow{2}{*}{$\begin{array}{c}\text { Nutrient } \\
\text { gap } \\
\text { 2011-12 }\end{array}$} \\
\hline & Mean & Mean & & & & \\
\hline Protein $(\mathrm{g})$ & 45.61 & 41.16 & -4.45 & 60 & -14.39 & -18.84 \\
\hline Fat $(\mathrm{g})$ & 43.96 & 23.99 & -19.97 & 30 & 13.96 & -6.01 \\
\hline Crude fibre $(\mathrm{g})$ & 5.90 & 6.53 & 0.63 & 40 & -34.1 & -33.47 \\
\hline Carbohydrates (g) & 294.98 & 273.36 & -21.62 & 375 & -80.02 & -101.64 \\
\hline Energy K.cal. & 1764.81 & 1478.12 & -286.69 & 2730 & -965.19 & -1251.88 \\
\hline Calcium (mg) & 451.72 & 337.32 & -114.4 & 600 & -148.28 & -262.68 \\
\hline Phosphorus (mg) & 1061.06 & 938.93 & -122.13 & 600 & 461.06 & 338.93 \\
\hline Iron $(\mathrm{mg})$ & 16.47 & 17.28 & 0.81 & 17.00 & -0.53 & 0.28 \\
\hline Vitamin A carotene $(\mu \mathrm{g})$ & 1265.01 & 1323.19 & 58.18 & 4800 & -3534.99 & -3476.81 \\
\hline Vitamin B1 thiamine (mg) & 1.33 & 1.23 & -0.1 & 1.40 & -0.07 & -0.17 \\
\hline Vitamin B2 riboflavin (mg) & 0.77 & 0.61 & -0.16 & 1.60 & -0.83 & -0.99 \\
\hline Vitamin B6 niacin (mg) & 15.28 & 14.48 & -0.8 & 18.00 & -2.72 & -3.52 \\
\hline Vitamin B12 folic acid (mg) & 129.22 & 134.06 & 4.84 & 200 & -70.78 & -65.94 \\
\hline Vitamin C (mg) & 74.39 & 91.39 & 17 & 40 & 34.39 & 51.39 \\
\hline
\end{tabular}

Table.5 Average intake of different nutrients among middle income urban households in Tamil Nadu

\begin{tabular}{|c|c|c|c|c|c|c|}
\hline \multirow[b]{2}{*}{ Foods/Nutrients } & 2004-05 & 2011-12 & \multirow{2}{*}{$\begin{array}{l}\text { Change } \\
\text { between } \\
\text { periods }\end{array}$} & \multirow{2}{*}{$\begin{array}{c}\text { Standard } \\
\text { per day } \\
\text { requirement* }\end{array}$} & \multirow{2}{*}{$\begin{array}{c}\text { Nutrient } \\
\text { gap } \\
\text { 2004-05 }\end{array}$} & \multirow{2}{*}{$\begin{array}{c}\text { Nutrient } \\
\text { gap } \\
2011-12\end{array}$} \\
\hline & Mean & Mean & & & & \\
\hline Protein $(\mathrm{g})$ & 62.15 & 51.83 & -10.32 & 60 & 2.15 & -8.17 \\
\hline Fat $(\mathrm{g})$ & 87.74 & 37.17 & -50.57 & 30 & 57.74 & 7.17 \\
\hline Crude fibre (g) & 7.44 & 8.55 & 1.11 & 40 & -32.56 & -31.45 \\
\hline Carbohydrates (g) & 352.78 & 294.60 & -58.18 & 375 & -22.22 & -80.4 \\
\hline Energy K.cal. & 2462.56 & 1726.77 & -735.79 & 2730 & -267.44 & -1003.23 \\
\hline Calcium (mg) & 762.54 & 444.39 & -318.15 & 600 & 162.54 & -155.61 \\
\hline Phosphorus (mg) & 1429.22 & 1132.19 & -297.03 & 600 & 829.22 & 532.19 \\
\hline Iron (mg) & 20.31 & 21.54 & 1.23 & 17.00 & 3.31 & 4.54 \\
\hline Vitamin A carotene $(\mu \mathrm{g})$ & 2007.85 & 1848.13 & -159.72 & 4800 & -2792.15 & -2951.87 \\
\hline Vitamin B1 thiamine (mg) & 1.65 & 1.44 & -0.21 & 1.40 & 0.25 & 0.04 \\
\hline Vitamin B2 riboflavin (mg) & 1.21 & 0.81 & -0.4 & 1.60 & -0.39 & -0.79 \\
\hline Vitamin B6 niacin (mg) & 18.24 & 15.89 & -2.35 & 18.00 & 0.24 & -2.11 \\
\hline $\begin{array}{l}\text { Vitamin B12 folic acid } \\
\text { (mg) }\end{array}$ & 168.86 & 172.69 & 3.83 & 200 & -31.14 & -27.31 \\
\hline Vitamin C (mg) & 106.12 & 124.77 & 18.65 & 40 & 66.12 & 84.77 \\
\hline
\end{tabular}


Table.6 Average intake of different nutrients among high income urban households in Tamil Nadu

\begin{tabular}{|c|c|c|c|c|c|c|}
\hline \multirow[b]{2}{*}{ Nutrients } & 2004-05 & 2011-12 & \multirow{2}{*}{$\begin{array}{c}\text { Change } \\
\text { between } \\
\text { periods }\end{array}$} & \multirow{2}{*}{$\begin{array}{c}\text { Standard } \\
\text { per day } \\
\text { requirement* }\end{array}$} & \multirow{2}{*}{$\begin{array}{l}\text { Nutrient } \\
\text { gap } \\
2004-05\end{array}$} & \multirow{2}{*}{$\begin{array}{l}\text { Nutrient } \\
\text { gap } \\
\text { 2011-12 }\end{array}$} \\
\hline & Mean & Mean & & & & \\
\hline Protein $(\mathrm{g})$ & 64.29 & 65.77 & 1.48 & 60 & 4.29 & 5.77 \\
\hline Fat $(\mathrm{g})$ & 144.74 & 54.09 & -90.65 & 30 & 114.74 & 24.09 \\
\hline Crude fibre $(\mathrm{g})$ & 8.22 & 11.71 & 3.49 & 40 & -31.78 & -28.29 \\
\hline Carbohydrates (g) & 271.65 & 307.46 & 35.81 & 375 & -103.35 & -67.54 \\
\hline Energy K.cal. & 2667.26 & 1989.76 & -677.5 & 2730 & -62.74 & -740.24 \\
\hline Calcium (mg) & 1151.06 & 613.11 & -537.95 & 600 & 551.06 & 13.11 \\
\hline Phosphorus (mg) & 1433.46 & 1373.56 & -59.9 & 600 & 833.46 & 773.56 \\
\hline Iron (mg) & 18.43 & 27.67 & 9.24 & 17.00 & 1.43 & 10.67 \\
\hline $\begin{array}{c}\text { Vitamin A carotene } \\
(\mu \mathrm{g})\end{array}$ & 2984.53 & 2774.84 & -209.69 & 4800 & -1815.47 & -2025.16 \\
\hline $\begin{array}{l}\text { Vitamin B1 thiamine } \\
(\mathrm{mg})\end{array}$ & 1.42 & 1.69 & 0.27 & 1.40 & 0.02 & 0.29 \\
\hline $\begin{array}{c}\text { Vitamin B2 riboflavin } \\
(\mathrm{mg})\end{array}$ & 1.59 & 1.12 & -0.47 & 1.60 & -0.01 & -0.48 \\
\hline $\begin{array}{l}\text { Vitamin B6 niacin } \\
(\mathrm{mg})\end{array}$ & 13.50 & 17.01 & 3.51 & 18.00 & -4.5 & -0.99 \\
\hline $\begin{array}{l}\text { Vitamin B12 folic acid } \\
\text { (mg) }\end{array}$ & 167.22 & 228.20 & 60.98 & 200 & -32.78 & 28.2 \\
\hline Vitamin C (mg) & 153.36 & 189.13 & 35.77 & 40 & 113.36 & 149.13 \\
\hline
\end{tabular}

Figure.1 Average intake of different nutrients among low income rural households

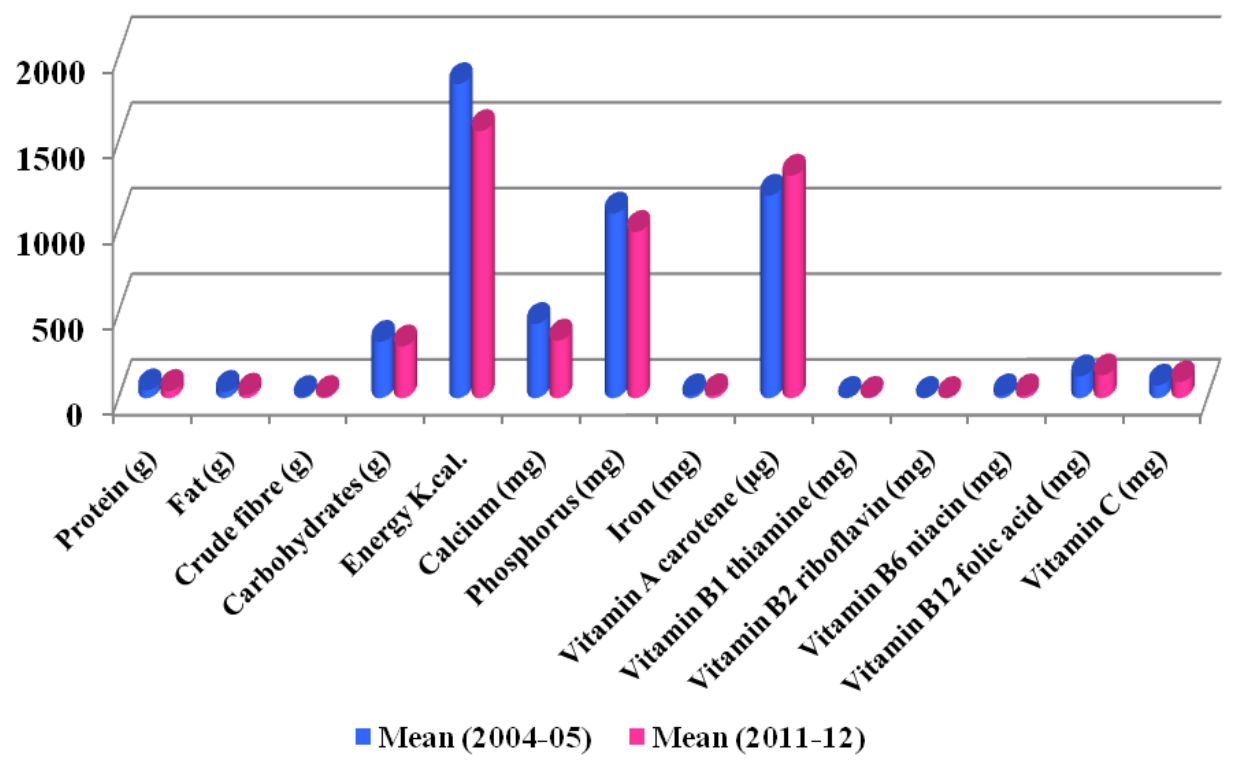


Figure.2 average intake of different nutrients among middle income rural households in Tamil Nadu

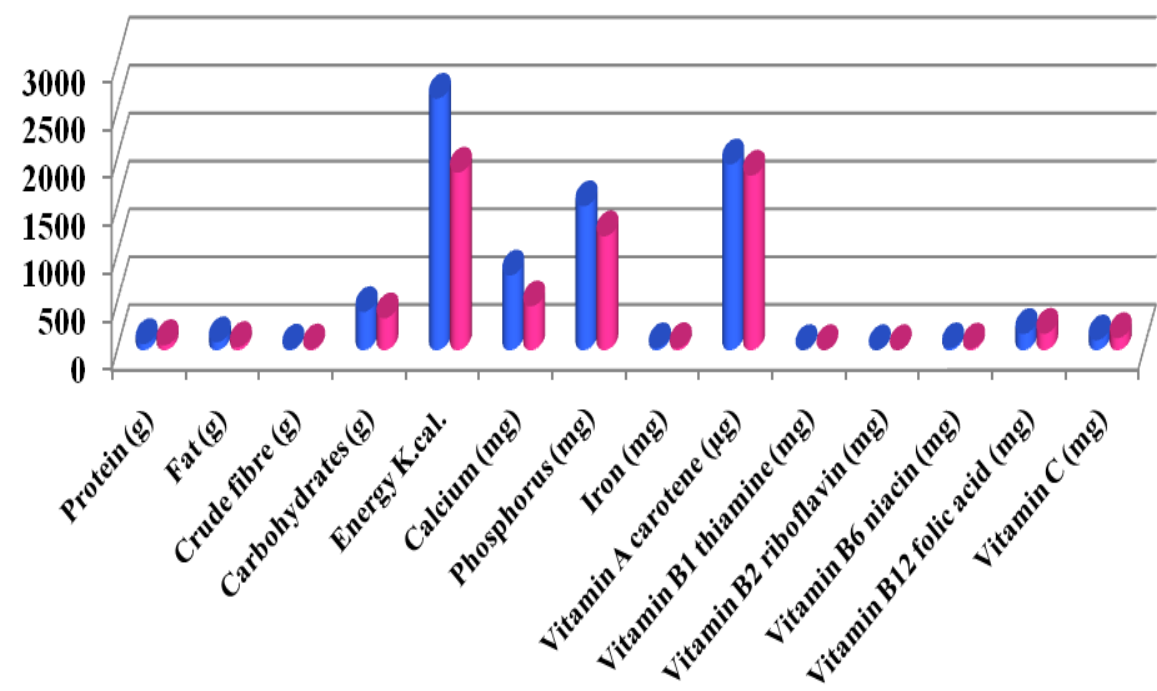

- Mean(2004-05) $\quad \operatorname{Mean}(\mathbf{2 0 1 1 - 1 2})$

Figure.3 Average intake of different nutrients among high income rural households in Tamil Nadu
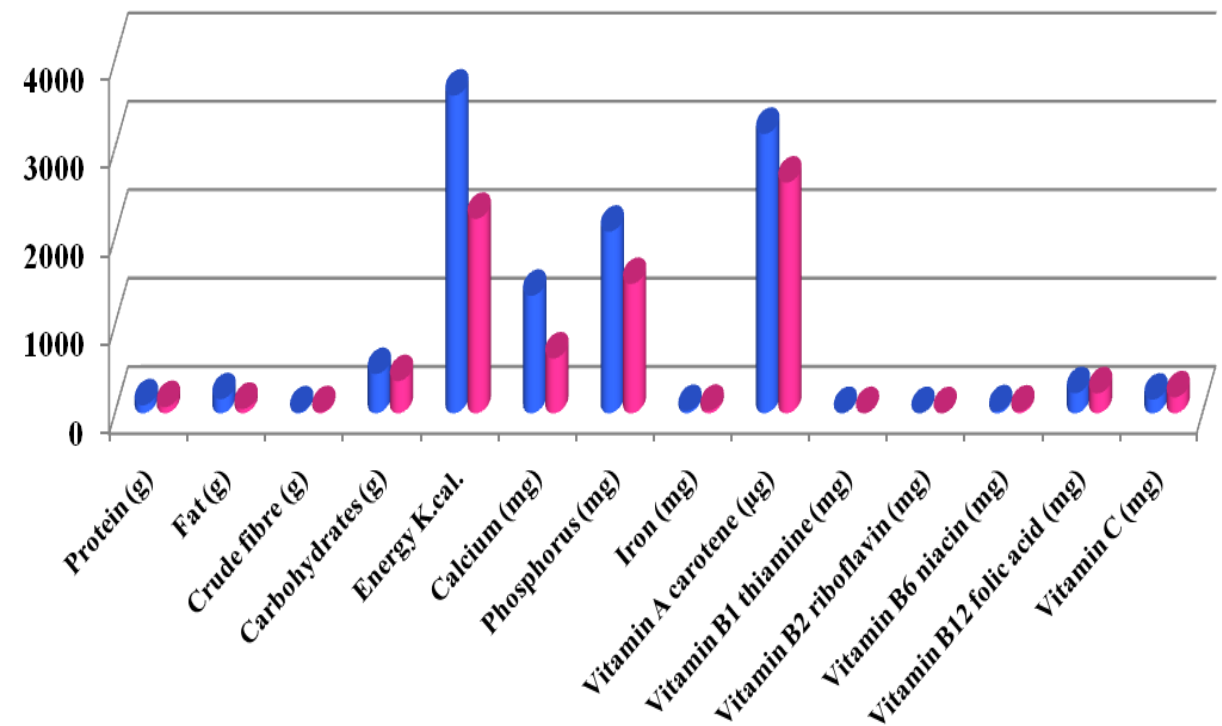

$\square \operatorname{Mean}(\mathbf{2 0 0 4 - 0 5 )} \quad \square \operatorname{Mean}(2011-12)$ 
Figure.4 Average intake of different nutrients among low income urban households in Tamil Nadu

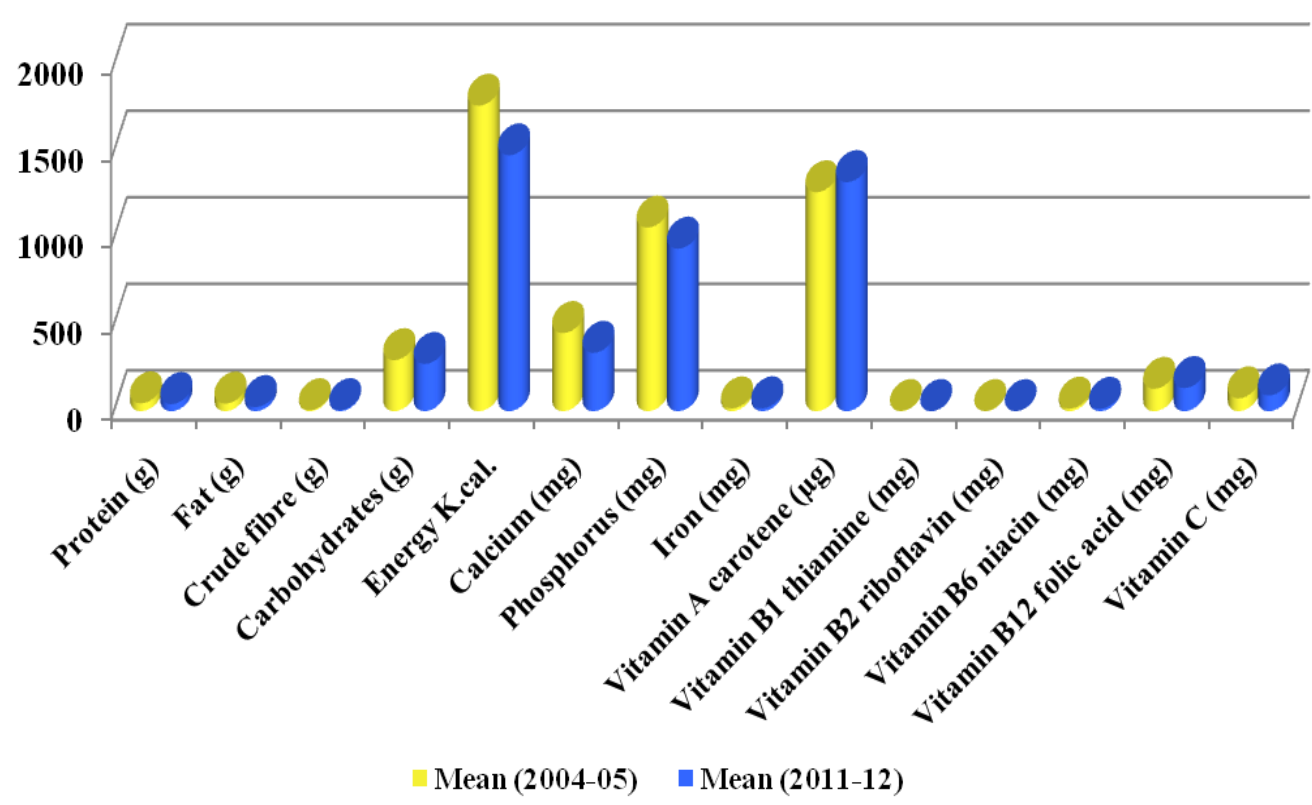

Figure.5 Average intake of different nutrients among middle income urban households in Tamil Nadu

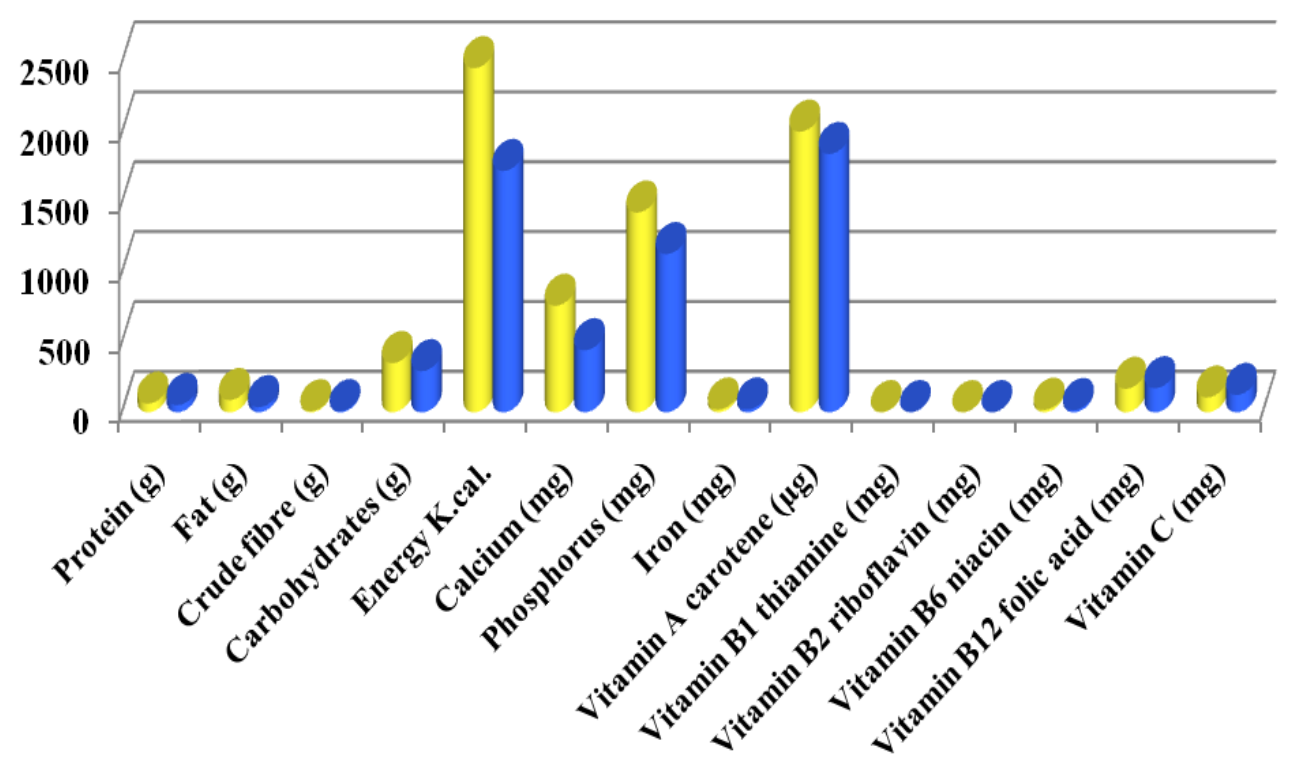


Figure.6 Average intake of different nutrients among high income urban households in Tamil Nadu

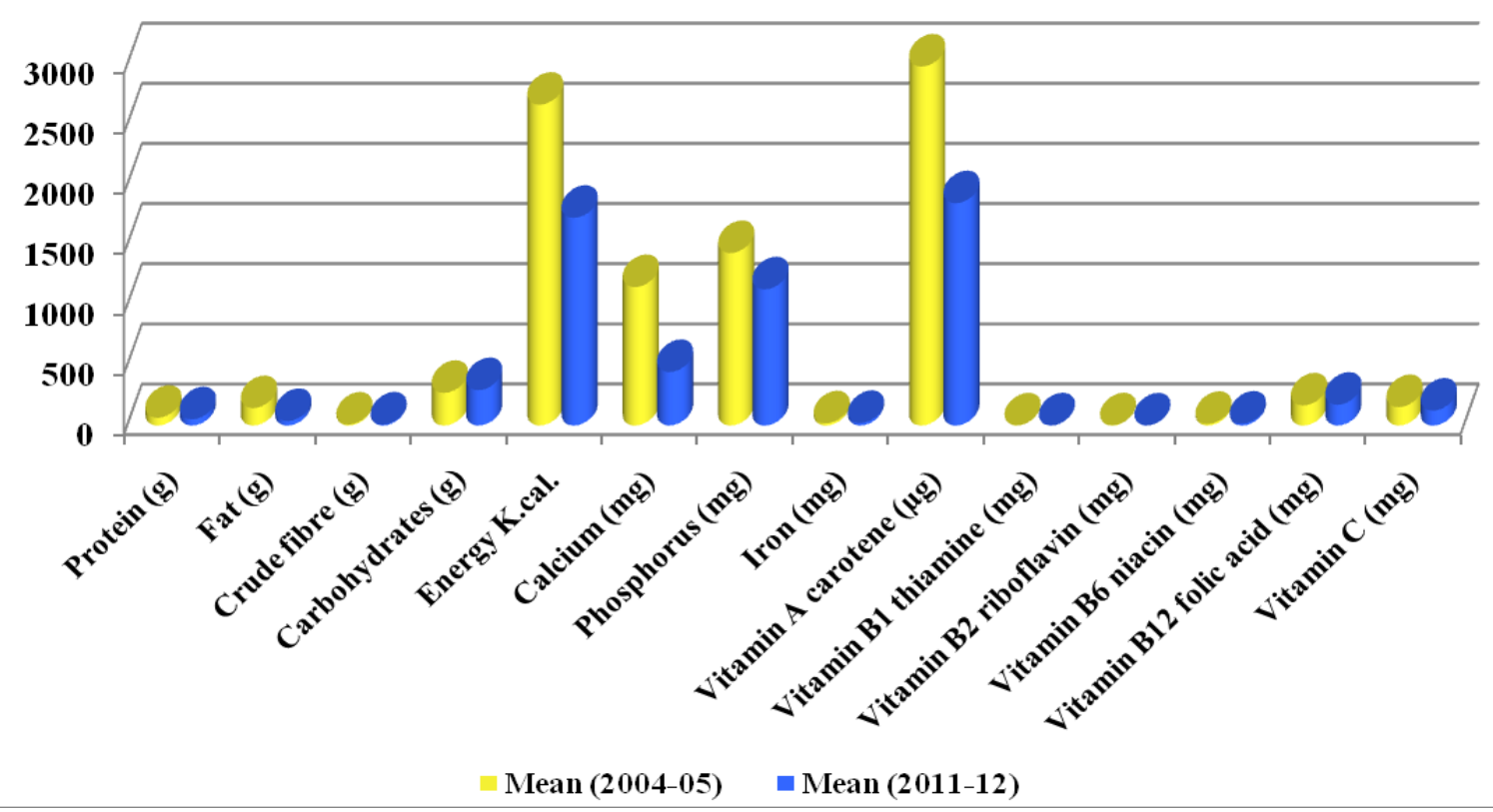

Average per day per capita intake of different types of nutrients among high income households in rural regions of Tamil Nadu is presented in table 3 and depicted as figure 3. From table 3 , it could be observed that average intake of all the nutrients were decreased, except crude fibre, iron and vitamins $C$ between 2004-05 and 2011-12. The maximum decrease in the nutrients was observed in the case of energy and calcium. The comparative analysis on the nutritional gap with respect to Recommended Daily Dietary Allowances (RDA) between 2004-05 and 2011-12 indicated that the degree of existing gap in 2004-05 got widened in the case of nutrients such as carbohydrates, energy and vitamin A. In the case of iron and Vitamin C, the intake was found to be more than RDA in 2004-05 while the intake decreased in the case of phosphorus and increased in the case of iron in 2011-12.

Average per day per capita intake of different types of nutrients among poor income people in urban regions of Tamil Nadu is presented in table 4 and depicted as figure 4 . From table 4 , it could be observed that average intake of all the nutrients were decreased, except crude fibre, iron and vitamins $\mathrm{C}$ and B12 between 2004-05 and 2011-12. The maximum decrease in the nutrients was observed in the case of energy and phosphorus. The comparative analysis on the nutritional gap with respect to Recommended Daily Dietary Allowances (RDA) between 2004-05 and 2011-12 indicated that the degree of existing gap in 2004-05 got widened in the case of nutrients such as protein, carbohydrates, calcium, vitamin B1, B2 and B6. In the case of phosphorus and Vitamin $\mathrm{C}$, the intake was found to be more than RDA in 2004-05 while the intake decreased in the case of phosphorus and increased in the case of Vitamin $\mathrm{C}$ in 2011-12.

Average per day per capita intake of different types of nutrients among middle income households in urban regions of Tamil Nadu is presented in table 5 and depicted as figure 5. From table 5, it could be observed that 
average intake of all the nutrients were decreased, except crude fibre, iron and vitamins B12 and C between 2004-05 and 2011-12. The maximum decrease in the nutrients was observed in the case of energy and calcium. The comparative analysis on the nutritional gap with respect to Recommended Daily Dietary Allowances (RDA) between 2004-05 and 2011-12 indicated that the degree of existing gap in 2004-05 got widened in the case of nutrients such as protein, carbohydrates, calcium, vitamin B1, B2 and B6. In the case of phosphorus and Vitamin $C$, the intake was found to be more than RDA in 2004-05 while the intake decreased in the case of phosphorus and increased in the case of Vitamin C in 201112.

Average per day per capita intake of different types of nutrients among higher income households in urban regions of Tamil Nadu is presented in table 6 and depicted as figure 6 . From table 6, it could be observed that average intake of all the nutrients were decreased, except crude fibre, carbohydrate, iron and vitamins B1, B6, B12 and C between 2004-05 and 2011-12. The maximum decrease in the nutrients was observed in the case of energy and calcium. The comparative analysis on the nutritional gap with respect to Recommended Daily Dietary Allowances (RDA) between 2004-05 and 2011-12 indicated that the degree of existing gap in 2004-05 got widened in the case of nutrients such as protein, calcium, vitamin B1, B2 and B6. In the case of phosphorus and Vitamin C, the intake was found to be more than RDA in 2004-05 while the intake decreased in the case of phosphorus and increased in the case of Vitamin C in 2011-12.

It is concluded that the average intakes of all the nutrients were decreased except crude fibre, iron, vitamin B12 and C between the periods 2004-05 and 2011-12 both in rural and urban households. The maximum decrease in nutrients were observed in case energy, calcium and phosphorous. The comparative analysis on the nutritional gap with respect to Recommended Daily Dietary Allowances (RDA) between 2004-05 and 2011-12 indicated that the gap got widened in the case of nutrients such as carbohydrate, protein, calcium, vitamin B1, vitamin B2 vitamin $\mathrm{B} 6$ and vitamin $\mathrm{C}$ and the intake exceeded the RDA in vitamin $\mathrm{C}$ and phosphorus in both rural and urban households over years and efforts on the part of Department of Health and Family Welfare to create awareness on the importance of major and minor nutrients, minerals, vitamins and the production, popularization and distribution of the food preparations containing all these nutrients have become the need of the hour and the allocation of required resources towards the creation of awareness and supply of nutrient rich food preparation should be undertaken in all the districts of Tamil Nadu.

\section{Acknowledgement}

My words are weak to express my indebtedness to my Chairman, Dr. D. David Rajasekar, Professor, Department of Agricultural Economics, Tamil Nadu Agricultural University, Coimbatore. Grace of almighty has always been felt in having given me this unique, dexterous personality to guide and inspire me with his soft, sincere, valuable suggestions, to pen this thesis. I owe him a lot for ever.

\section{References}

Bhargava, A. 1991. Estimating Short and Long Run Income Elasticities of Foods and Nutrients for Rural South India, $J$. Royal Stat. Society, 154(1): 157-174.

Deaton, A. and Dreze, J. 2009. Food and nutrition in India: Facts and 
interpretations. Economic and Political Weekly, 44(7): 42-65.

Gopalan, C., Ramasastri, B.V. and Balasubramanian, S.C. 1996. Nutritive Value of Indian Foods. National Institute of Nutrition, Indian Council of Medical Research, Hyderabad.

Gopalan, C., Shastri, B.V.R. and Balasubramanian, S.C. 2009. Nutritive value of Indian foods, Hyderabad: National Institute of Nutrition, ICMR.

Gupta, A. and Mishra, D.K. 2013. Poverty and calorie deprivation across socioeconomic group in rural India: A Disaggregated analysis, J. Regional Develop. Planning, 2(1): 15-33.

Mallikharjuna, Balakrishna, et al. 2010. IN, "ICMR: diet and nutritional status of women in India", J. Human Ecol., vol. 29, no.3, pp. 165-170.

Popkin, B.M. 2009. The World is Fat: The Fads, Trends, Policies and Products that are fattening the Human Race, Penguin.

\section{How to cite this article:}

Naveen Kumar, P., K. Thomas Felix and David Rajasekar, D. 2017. An Economic Analysis of Changes in the Per Capita Nutrient Intake and Nutritional Inadequacy in Tamil Nadu, India. Int.J.Curr.Microbiol.App.Sci. 6(3): 2265-2275. doi: http://doi.org/10.20546/ijcmas.2017.603.259 